\title{
Irrigation in the Tarim Basin, China: farmers' response to changes in water pricing practices
}

\author{
Yusuyunjiang Mamitimin • Til Feike • \\ Isabel Seifert $\cdot$ Reiner Doluschitz
}

Received: 9 August 2013/ Accepted: 28 March 2014/Published online: 16 April 2014

(C) The Author(s) 2014. This article is published with open access at Springerlink.com

\begin{abstract}
The extremely arid Tarim Basin in northwestern China is an important cotton and fruit production region. However, extensive agricultural land reclamation combined with unreasonable water use in recent decades resulted in degradation of ecosystems along the Tarim River. With declining water availability, it is becoming increasingly important to utilize this essential resource more efficiently. Water pricing is considered an effective way to advance water allocation and water conservation. To identify whether a strong increase in water price may lead to a wiser agricultural water use along Tarim River, 128 farmers were interviewed with structured questionnaire in different parts of the Basin. Multinomial logistic regression was employed to explain the factors influencing farmers' reaction towards a strong increase in water price. The results show that under increased water price less than half of the interviewed farmers would opt for decisions that lead to improved water use efficiency. Moreover, the price increase might lead to a further expansion of groundwater exploitation in the region. Fruit farmers, as well as farmers with less land and less cash income are reluctant to adopt advanced irrigation technology or improve their crop production in reaction to increased water price. It was furthermore revealed that the experience of slight water shortage in the past created awareness by farmers to use water more wisely. It is concluded that the sole increase of water price is not a viable option; an integrated approach is
\end{abstract}

Y. Mamitimin $(\bowtie) \cdot T$. Feike $\cdot$ R. Doluschitz

Institute of Farm Management (410c),

Universität Hohenheim, Stuttgart, Germany

e-mail: Y.Mamitimin@uni-hohenheim.de

I. Seifert

Section of Climate and Environmental Modeling,

Norwegian Institute of Water Research, Oslo, Norway necessary, in which creation of awareness and improving agronomic skills of farmers play a key role to overcome the tight water situation and realize a more efficient use of water.

Keywords Water scarcity · Water pricing · Farmers' decisions · TARIM Basin, China $\cdot$ Multinomial logistic regression

\section{Introduction}

Irrigated agriculture is the biggest consumer of water resources, accounting for more than $70 \%$ of the world's fresh water usage. It plays an important role in global food production, nourishing the urban poor at affordable prices, while providing job opportunities in rural areas (Tiwari and Dinar 2001; Reddy 2009). Population growth and increased levels of income, however, have caused an increased water demand (Tsur 2005), making it a more and more scarce resource in many locations throughout the world.

With the decline of water availability becoming more evident, it is imperative to allocate and use this essential resource as efficiently as possible. In many arid regions of the world past water resource policies in many countries have fostered the development of irrigation capacities, while attempting to guarantee the supply of water to the residential users (Aishan et al. 2013; Chen et al. 2013a; Varela-Ortega et al. 1998). Water resource development was based on constant supply augmentation. As this was in many cases associated with high financial and environmental cost, the focal point has shifted towards demanddriven water management. Winpenny (1994) described this new viewpoint aptly as "doing better with what we have", in opposition to the theorem of steady supply increases. 
The Tarim River is the longest inland river in China, located in the extremely arid southern part of Xinjiang Uyghur Autonomous Region. Even though very dry, the region is an important cotton and fruit production base. However, extensive land reclamation over the last 60 years combined with unreasonable water exploitation led to a continuous reduction of water flowing to the mainstream of Tarim River, which resulted in severe degradation of ecosystems along the lower reaches of the river (Jiang et al. 2005; Xu et al. 2012; Wu 2012; Fu et al. 2012; Zhao et al. 2013). In addition, water scarcity is considered the major factor impairing the ecological, social and economic development of the region (Chen et al. 2013a, b; Zhou et al. 2012). It is recognized that the rational distribution and effective utilization of water resources are the key to a sustainable development along the Tarim River (Xu et al. 2005; Ye et al. 2006).

Water pricing, as an important socio-economic tool, is considered the most effective way to advance water allocation and water conservation by several scholars (e.g., Tsur and Dinar 1997). Firstly, water pricing can help to ensure cost recovery from the users, which provides funds to sustain the water supply system (Abu-Zeid 2001). According to Dinar and Subramanian (1998) water pricing encourages water users to utilize this valuable resources more wisely by giving them information on water's economic, or scarcity value. Schoengold et al. (2006) confirmed that an increase in marginal water price leads to reduced water application and may encourage a shift in cropping patterns. In contrast, Molle (2008) argues that the potential of pricing irrigation water to improve water allocation and regulate water use is often lower than expected. In a case study in India only a substantial increase in water pricing rates showed the desired effects (Singh 2007). Perry (2001) already claimed that the price of water must be significant, and that the actual prices are generally too low to be effective. The downside of such proclaimed substantial increases in water prices is described by several research groups. Those argue that increasing water price may not only lead to a reduction in agricultural production, but may additionally increase rural poverty (Tardieu and Prefol 2002; Liao et al. 2007). Other case studies showed that increasing water pricing may cause over-utilization of groundwater resources (Schuck and Green 2003; Liao et al. 2008). Thus, the design and implementation of the water pricing process need to be conducted with great care, taking into account economic consequences and other external effects (Liao et al. 2007; Schuck and Green 2003; Tardieu and Prefol 2002; Tsur 2005). All requirements regarding legal and regulatory framework, operational criteria, and economic criteria need to be addressed to realize an effective water pricing system (Perry 2001).
In the Tarim Basin only very limited research on the role of water pricing in sustainable resource use has been conducted up to now. Shen and Haakon (2010) undertook a qualitative study in the Kaidu-Kongque River Basin, a subbasin of the Tarim Basin, based on secondary data and a qualitative survey. They conclude that pricing of water did not contribute to a more efficient water use, but it mainly strengthened a growing bureaucratic body of water administration. Even though their investigations contributed to the general understanding of the role of water pricing in the region, the farmers, as the actual water users, holding a key role in sustainable resource use, are up to now insufficiently considered in the water pricing issue. Their perception of water pricing as well as their reaction towards changes in pricing policies is heavily under investigated in the Tarim Basin.

Therefore, the overall objective of this study is to identify whether a strong increase in water price may lead to a wiser use of scarce water resources by farmers along the Tarim River. The specific objectives are: (1) to find out farmers' response towards increase in water price, (2) to identify the factors influencing farmers' response towards increase in water price, and (3) to develop policy recommendations aiming at the wiser use of water by farmers, and related increase of water use efficiency (WUE) in the Tarim Basin.

\section{Materials and methods}

\section{Study area}

More than 1,300 km long Tarim River is located along the northern edge of Taklimakan Desert (Fig. 1). Its Basin is characterized by an extremely continental climate, arid with very little precipitation and very high evaporation (Huang et al. 2011). Snow precipitating in the mountainous areas constitutes the major part of total precipitation in the Basin. Water streams nourished by snow and glacier-melt from the surrounding mountain ranges form the Tarim River (Xu et al. 2005; de la Paix et al. 2012). Its three major tributaries-the Aksu River, Yarkant River and Hotan River contribute $78.11,0.54$ and $21.35 \%$ to its total discharge, respectively (Song et al. 2002). Due to high water abstraction in the headwater of the tributaries, only Aksu River delivers water permanently to the Tarim River in recent years, while the other two rivers discharge water only sporadically during times of floods.

The Tarim River represents a closed and independent hydrological system. While the annual runoff is mainly determined by the volume of snow and glacier-melt, showing seasonal variation with the alteration of temperature, the total annual discharge is rather stable (Jiang et al. 2005). 


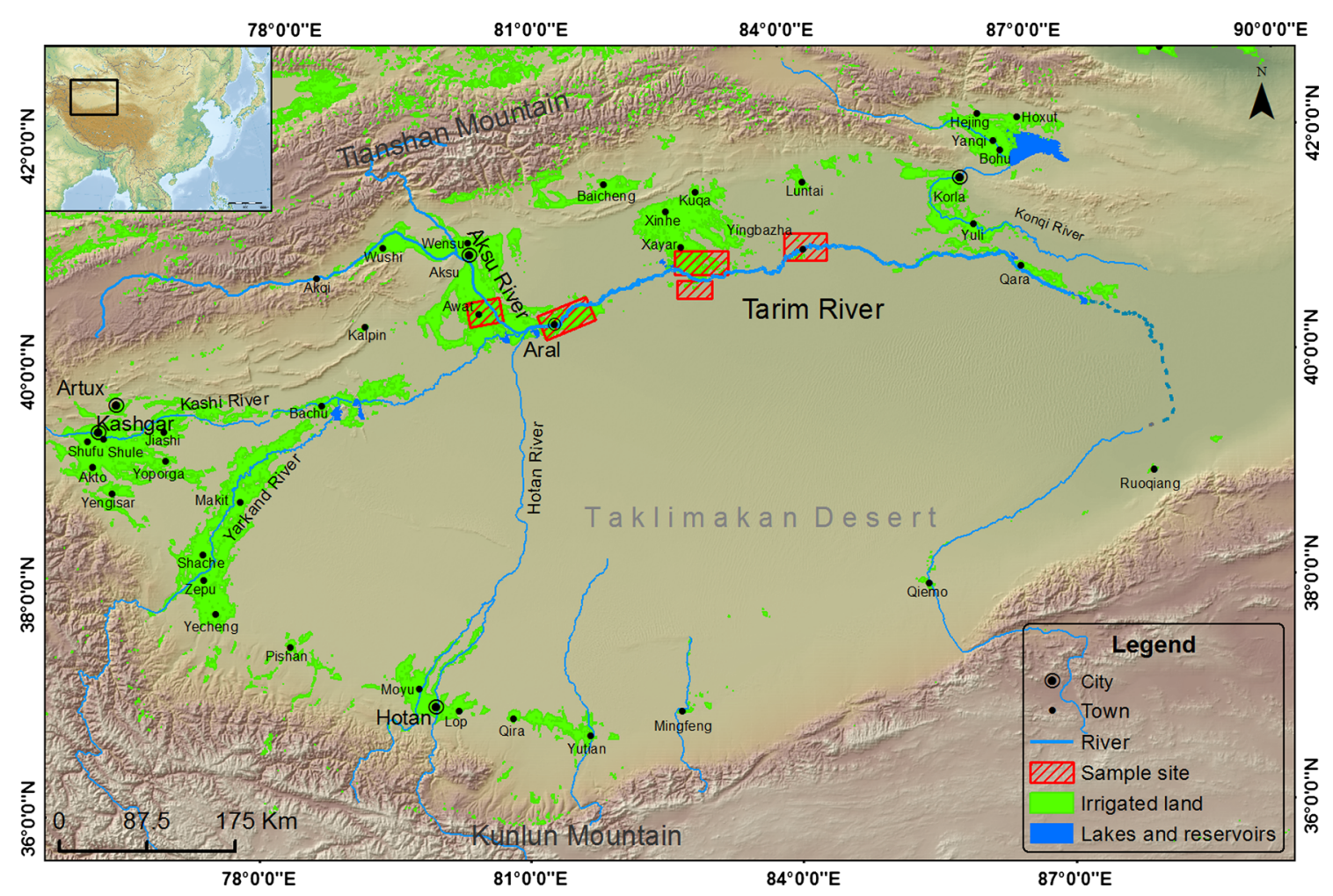

Fig. 1 Tarim Basin with the Tarim River stretching along the northern edge of the Taklimakan desert, and the location of the five survey sites along the river

Data collection

This study is based on data collected from 128 farm household interviews conducted with structured quantitative questionnaire. Five survey regions were selected purposefully based on their specific location in the direct vicinity of the Tarim River; agricultural production in those five regions solely depends on the fresh water resources provided by the Tarim, or its main tributary the Aksu River. The five regions are Aksu-Awat, Alar, Xayar-North (Xayar county north of Tarim River), Xayar-South (Xayar county south of Tarim River) and Yingbazha (Fig. 1). The number of surveyed farm households at each sample site is 28, 20, 45, 19 and 16, respectively. Respondents were selected randomly, and were informed at the beginning of the interview that the purpose of the interview was purely scientific. Before actual data collection, the quantitative questionnaire was subjected to pilot test to ascertain clarity. Specific changes regarding on-farm water management and experienced water scarcity were made after the pilot test. Except the Alar region, which comprises the Division 1 of the Xinjiang Production and Construction Corps (XPCC), a special economic and semi-military organization of Xinjiang province, the other four survey sites represent typical local regions. Therefore, the surveyed data can be considered to represent the general situation along the Tarim
River. The survey was conducted in July and August 2012. The questions related to crop production and water availability comprised the previous year's conditions in 2011, as the cropping season 2012 was not yet finished during the time of interviews.

Estimating the effect of water price increase

To assess the impact of water pricing on farmers' decision making several research groups applied mathematical programming approaches that build on the concept of constraint profit maximization (e.g., Albiac et al. 2007; Berbel and Gómez-Limón 2000; Doppler et al. 2002; Gómez-Limón and Riesgo 2004). The challenges often occurring in those modeling approaches are overspecialization of production and unfeasible model calibration, as described by, e.g., Hazell and Norton (1986), Henseler et al. (2009), and Howitt (1995). By integrating the occurrence of inefficiencies in their models Speelman et al. (2009) as well as Frija et al. (2011) could overcome some of the previously described difficulties, enabling them to integrate the actual input and output data of all their sampled farms, thus generating more realistic results. Still the basic assumption of the farmer acting purely as a homo economicus, i.e., economic profit maximization is the farmer's only driver, has its obvious shortcomings. In 
Table 1 Detailed description of five options to respond to a $100 \%$ increase in water price as explained to the farmers during field survey

\begin{tabular}{ll}
\hline Options & Detailed description \\
\hline Drill a well & $\begin{array}{c}\text { Farmer drills a well to make groundwater } \\
\text { available as alternative irrigation water } \\
\text { source }\end{array}$ \\
$\begin{array}{l}\text { Do nothing, just pay } \\
\text { higher price } \\
\text { and continues crop production, farm } \\
\text { management, and water resource use as } \\
\text { before }\end{array}$ \\
$\begin{array}{l}\text { Farmer shifts crop pattern to crops with } \\
\text { higher water productivity; i.e., crops that } \\
\text { generate a higher return per invested } \\
\text { unit of water }\end{array}$ \\
$\begin{array}{l}\text { Farmer improves farm management } \\
\text { aiming at a reduction of existing yield } \\
\text { gaps and minimization of water losses } \\
\text { management practices }\end{array}$ \\
$\begin{array}{l}\text { Farmer shifts to advanced irrigation } \\
\text { technology; technological levels are } \\
\text { irrigation technology } \\
\text { increasing with flood irrigation } \\
\text { constituting the lowest level, followed } \\
\text { by furrow irrigation, sprinkler irrigation, } \\
\text { drip irrigation, and ultimately demand- } \\
\text { driven drip irrigation }\end{array}$ \\
\hline
\end{tabular}

addition to the economic forces farmers' decision making is strongly influenced by their social and cultural context, as well as their personal experience and risk aversion attitude. Those factors can only insufficiently be handled in the above described modeling approaches.

Therefore, to assess the effect of a strong increase of water price on farm management and respective on-farm water resource management, we conducted an explorative study. We confronted the farmers in the study region with a potential $100 \%$ increase in water price, and asked for their reaction in response to this increase. The possible options, which the farmers could choose from, were derived in a two-step procedure. First, potential reactions by farmers to an increase in water price were discussed with local experts in the frame of a stakeholder workshop on "Agricultural Water Use" conducted in the provincial capital Urumqi in August 2011. Second, the identified options were tested in the pilot survey. Finally, farmers were given five different options to answer the question: "What would you do if water price increases by 100 percent?" Those were (1) 'drill a well', (2) 'do nothing and just pay higher water price', (3) 'shift crop pattern', (4) 'optimize on-farm management practices', and (5) 'adopt improved irrigation technology', described in detail in Table 1. Even though the presented approach is not able to capture a potentially gradual reaction by farmers towards increasing water prices, as identified by Frija et al. (2011) and Speelman et al. (2009), the applied approach has strong merit going beyond the pure profit maximization approaches. The additionally obtained data on farm household characteristics, e.g., age and education level, as well as the farms' crop production characteristics, e.g., major crop types and respective yields, allow the assessment of the determinants of farmers' decision making. Building on those results specific recommendations can be developed targeted at the respective household groups.

Unfortunately available literature on current water pricing practices, agricultural production conditions, and farm management in the study region is extremely poor. Therefore, we mainly build on our surveyed data to provide important background information regarding current water pricing practices and the five offered choices. Water pricing in the region is generally conducted on a per area basis. The water price that farmers pay to the local water authorities per hectare and year ranges from 900 to 1,500 RMB. According to Xinjiang Statistical Yearbook (2012) and XPCC Statistical Yearbook (2012) average annual net incomes of farm households in the study region range from 7,700 to 12,300 RMB. Thus, a $100 \%$ increase in water price would constitute a substantial decrease in farm incomes depending on the household's agricultural land use area. The cost for drilling a well is mainly determined by its depth. The costs for drilling a well strongly depend on the required depth to reach fresh water of sufficient quality, i.e., low salinity. As reported by the surveyed farmers the depths range from $20 \mathrm{~m}$ to more than $100 \mathrm{~m}$. Furthermore, the location-specific soil parent material determines the amount of invested energy and wear out of drilling equipment, which additionally influence the cost of a well. The reported costs range from 10,000 to 60,000 RMB per well. Even though various irrigation methods potentially available to farmers in the region (Table 1) were introduced to the respondents during the interview, only two methods are actually applied; flood irrigation and drip irrigation. The additional costs for applying drip irrigation technology are estimated at 5,100-7,500 RMB per hectare (Xu et al. 2003).

\section{Statistical analysis}

Apart from descriptive statistics, multinomial logistic regression, a variation of ordinary regression, was selected for analysis of the collected quantitative dataset. It is especially suitable for research questions that feature two or more categorical-dependent variables, and several continuous as well as categorical explanatory variables. It is a well-tested methodological approach, regularly applied in farm, forest and irrigation research (e.g., Bakopoulou et al. 2010; Christopoulou and Minetos 2009; Demeke et al. 2011).

The possible responses on "What would you do if water price increases by 100 percent?" represent the dependent 
Table 2 Description of variables used in the regression analysis

\begin{tabular}{|c|c|c|}
\hline \multicolumn{2}{|c|}{ Variables } & Type \\
\hline \multicolumn{3}{|c|}{ Independent variables } \\
\hline$X_{1}$ & Age & Continuous \\
\hline$X_{2}$ & Total land area & Continuous \\
\hline$X_{3}$ & Total cash income & Continuous \\
\hline$X_{4}$ & Education & Categorical \\
\hline$X_{5}$ & Location & Categorical \\
\hline$X_{6}$ & Number of Crops & Categorical \\
\hline$X_{7}$ & Main crop & Categorical \\
\hline$X_{8}$ & Fruits & Categorical \\
\hline$X_{9}$ & Water shortage & Categorical \\
\hline$X_{10}$ & Irrigation method & Categorical \\
\hline$X_{11}$ & Existence of well & Categorical \\
\hline \multicolumn{3}{|c|}{ Dependent variables } \\
\hline$Y_{1}$ & Drill a well & Multivariate \\
\hline$Y_{2}$ & Do nothing, just pay higher price & Multivariate \\
\hline$Y_{3}$ & Improve crop production & Multivariate \\
\hline$Y_{4}$ & Adopt improved irrigation technology & Multivariate \\
\hline
\end{tabular}

variables in the multinomial logistic regression model. The two responses 'optimize on-farm management practices' and 'shift crop pattern' were merged into a new category entitled 'improve crop production', due to the low number of farmers selecting those two choices (Table 2).

Multinomial logistic regression enables the comparison of each category of the dependent variable to a reference category, providing their probability. In this study, the dependent variable has four categories (Table 2). The first category $Y_{1}$ (drill a well) was selected as reference category. If there are $z$ explanatory variables $\left(x_{1}, x_{2}, \ldots, x_{z}\right)$ and $k$ response categories $\left(Y_{1}, Y_{2}, \ldots, Y_{k}\right)$, the logistic model can be written as:

$\ln \left(\frac{P_{i-\text { category }}}{P_{j-\text { category }}}\right)=a+b_{i 1} x_{1}+b_{i 2} x_{2}+\cdots+b_{i z} x_{z}+\varepsilon_{i}$

' $P_{i \text {-category' }}$ represents the likelihood of the dependent variable being in the $i$-category, while ' $P_{j \text {-category }}$ ' represents the likelihood of the dependent variable being in the $j$-category (the reference category). ' $a$ ' indicates the intercept of the regression curve, ' $b$ ' the coefficient of each predictor, and ' $\varepsilon$ ' represents the error term.

In this case, the three logits can be written as follows:

$Y_{2}=\ln \left(\frac{P_{Y_{2}}}{P_{Y_{1}}}\right)=a+b_{Y_{2} 1} X_{1}+b_{Y_{2} 2} X_{2}+\cdots+b_{Y_{2} z} X_{z}+\varepsilon_{Y_{2}}$

$Y_{3}=\ln \left(\frac{P_{Y_{3}}}{P_{Y_{1}}}\right)=a+b_{Y_{3} 1} X_{1}+b_{Y_{3} 2} X_{2}+\cdots+b_{Y_{3} z} X_{z}+\varepsilon_{Y_{3}}$
$Y_{4}=\ln \left(\frac{P_{Y_{4}}}{P_{Y_{1}}}\right)=a+b_{Y_{4} 1} X_{1}+b_{Y_{4} 2} X_{2}+\cdots+b_{Y_{4} z} X_{z}+\varepsilon_{Y_{4}}$

They express the $\log$ of the ratio of the probability a farmer chooses to 'adopt improved irrigation technology', 'improve crop production' and 'do nothing and just pay higher water price' compared to the probability a farmer chooses to 'drill a well' in case of increased water price.

\section{Results and discussion}

\section{Characteristics of farm households}

Table 3 illustrates the descriptive statistics of all variables used for multinomial logistic regression. The table shows the following continuous variables included in the analysis: farmers' age, total land area, and total cash income. The categorical variables included were: farmers' education level, ethnicity, location, number of crops, main crop, existence of water shortage, existence of fruit trees, existence of well and irrigation method.

The descriptive statistics show an average age of the surveyed farmers of 43 years, while average land area is 9.19 ha. Due to a few very huge land holdings surveyed in the Yingbazha area, which reach up to 233 ha, the average total land area per farm household is fairly large compared to provincial averages, reported at around 1 ha per farm household (Xinjiang Statistical Yearbook 2012). Thevs (2011) already reported about private investors reclaiming large areas of riparian land for cotton production especially along the middle reaches of the River, which confirms our observations revealed in a standard deviation of total land area of 26.32 ha. A similar discrepancy among farm households exists regarding their average total cash income, which was calculated from farmers' reported crop yields, sales prices and total production area of the respective crops. At a mean cash income of 351,109.58 RMB, standard deviation is more than 1 million RMB. Furthermore, a relatively low education level is prevalent among surveyed farmers, with $11 \%$ illiterate, $77 \%$ primary and middle school graduates, and only $12 \%$ having a high school or college degree. The ratio of Uighurs (68\%) and Han (32\%) within the sample approximately displays their ratio in Aksu prefecture and Bayangol prefecture as reported for 2011 (Feike et al. 2014).

The vast majority of farmers specialized on the production of a single crop ( $82 \%$ ), while only very few produced more than two different crops. The main crops produced were cotton, apple and jujube, with cotton being by far the most important crop. Only $28 \%$ of farmers produce fruits, while the majority does not. Queried about the water availability for crop production, more than half of the 
Table 3 Descriptive statistics of the independent variables
$1 \mathrm{RMB}=0.16$ USD (2012)

(Source: World Bank Database)

\begin{tabular}{|c|c|c|c|c|c|c|}
\hline \multicolumn{2}{|l|}{ Continuous variables } & $N$ & Minimum & Maximum & Mean & SD \\
\hline \multicolumn{2}{|l|}{ Age (years) } & 126.00 & 20.00 & 81.00 & 43.25 & 12.83 \\
\hline \multicolumn{2}{|l|}{ Total land area (ha) } & 128.00 & 0.27 & 233.33 & 9.19 & 394.65 \\
\hline \multicolumn{2}{|c|}{ Total cash income (RMB) } & 128.00 & 0.00 & $9,400,000$ & $351,109.58$ & $1,046,278.51$ \\
\hline $\begin{array}{l}\text { Categorical } \\
\text { variables }\end{array}$ & $N$ & Percent $(\%)$ & \multicolumn{4}{|l|}{ Description } \\
\hline \multicolumn{7}{|l|}{ Education } \\
\hline Illiterate & 13 & 10.4 & \multicolumn{4}{|c|}{ Illiterate $=1$, others $=0$} \\
\hline Lower education & 97 & 77.6 & \multicolumn{4}{|c|}{ Lower education (primary and middle school) $=1$, others $=0$} \\
\hline Higher education & 15 & 12.0 & \multicolumn{4}{|c|}{ Higher education (high school and college) $=1$, others $=0$} \\
\hline \multicolumn{7}{|l|}{ Ethnicity } \\
\hline Uyghur & 87 & 68.0 & \multicolumn{4}{|c|}{ Uyghur $=1$, other $=0$} \\
\hline Han & 41 & 32.0 & \multicolumn{4}{|c|}{ Han $=1$, other $=0$} \\
\hline \multicolumn{7}{|l|}{ Location } \\
\hline Aksu-Awat & 28 & 21.9 & \multicolumn{4}{|c|}{ Aksu-awat $=1$, others $=0$} \\
\hline Alar & 20 & 15.6 & \multicolumn{4}{|c|}{ Alar $=1$, others $=0$} \\
\hline Xayar-North & 45 & 35.2 & \multicolumn{4}{|c|}{ Xayar-North $=1$, others $=0$} \\
\hline Xayar-South & 19 & 14.8 & \multicolumn{4}{|c|}{ Xayar-South $=1$, others $=0$} \\
\hline Yingbazha & 16 & 12.5 & \multicolumn{4}{|c|}{ Yingbazha $=1$, others $=0$} \\
\hline \multicolumn{7}{|l|}{ Main crop } \\
\hline Cotton & 110 & 85.9 & \multicolumn{4}{|c|}{ Cotton $=1$, others $=0$} \\
\hline Other crops & 18 & 14.1 & \multicolumn{4}{|c|}{ Other crops (Red dates and apple) $=1$, other $=0$} \\
\hline \multicolumn{7}{|l|}{ Number of crops } \\
\hline One crop & 105 & 82.0 & \multicolumn{4}{|c|}{ One crop $=1$, other $=0$} \\
\hline Multiple crops & 23 & 18.0 & \multicolumn{4}{|c|}{ Multiple crops $=1$, other $=0$} \\
\hline \multicolumn{7}{|l|}{ Water shortage } \\
\hline No & 30 & 23.4 & \multicolumn{4}{|c|}{ No $=1$, others $=0$} \\
\hline Slight & 37 & 28.9 & \multicolumn{4}{|c|}{ Slight $=1$, others $=0$} \\
\hline High & 61 & 47.7 & High $=1, o$ & $\mathrm{rs}=0$ & & \\
\hline Fruits & & & & & & \\
\hline Yes & 36 & 28.1 & Yes $=1$, ot & $=0$ & & \\
\hline No & 92 & 71.9 & No $=1$, oth & $=0$ & & \\
\hline Existence of well & & & & & & \\
\hline Yes & 67 & 52.3 & Yes $=1$, ot & $=0$ & & \\
\hline No & 61 & 47.7 & No $=1$, oth & $=0$ & & \\
\hline Irrigation method & & & & & & \\
\hline Drip irrigation & 36 & 28.1 & Drip irrigati & $=1$, other $=$ & & \\
\hline Flood irrigation & 92 & 71.9 & Flood irriga & $=1$, other & & \\
\hline
\end{tabular}

interviewees stated that they suffered from different degrees of water shortage during the 2011 growing season. Regarding the irrigation method, the majority of farmers used flood irrigation $(71.9 \%)$, with the remaining farmers using drip irrigation. In addition, about half of the farmers already dug a well for alternative irrigation water supply in the past.

Farmers' response towards increased water price

Figure 2 illustrates farmers' response towards the increase in water price. It is shown that over the entire sample
(Fig. 2a), roughly one-third of farmers selected 'drill well', one-third 'adopt improved irrigation technology', and onefourth 'do nothing', with only very few farmers opting for 'shift crop pattern' and 'improve on-farm management practices'. As the increasing exploitation of groundwater resources is contributing to the aggravating water scarcity and consecutive degradation of natural ecosystems along the Tarim River in recent decades (Thevs 2011; Xu et al. 2005; Chen et al. 2013a, b), 'drill a well' should be considered the most undesirable reaction by farmers towards an increase in water price. Even though the responsible 
Fig. 2 Farmers' response towards the increase in water price over the overall sample (a) and distinguished between the five survey sites (b)

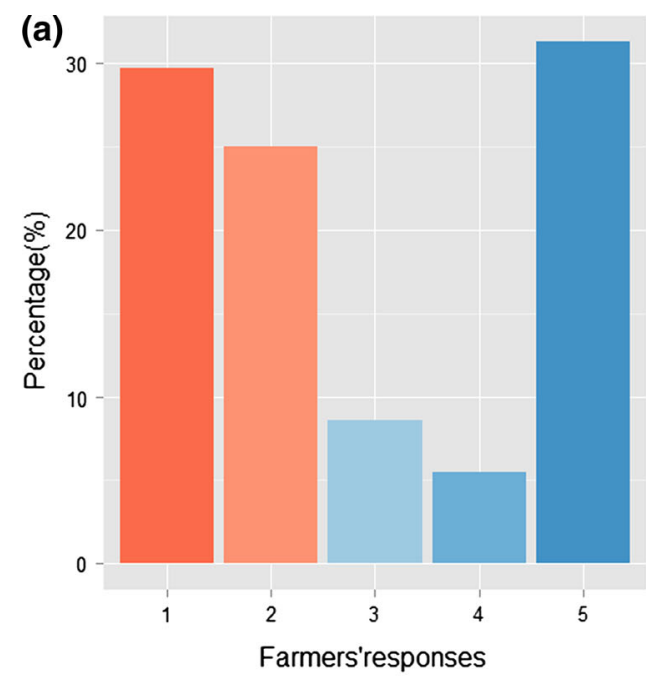

Drill a well Do nothing Shift crop patter

Optimize on-farm management practices Adopt improved irrigation technology

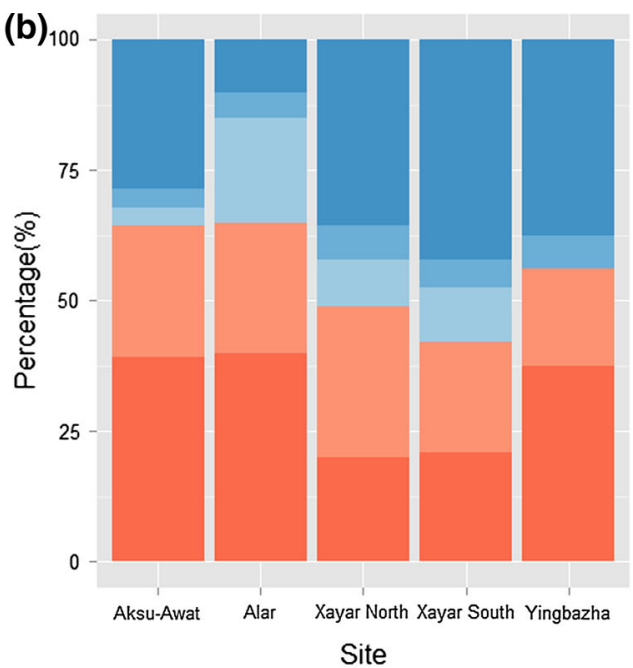

Drill a well Do nothing Shift crop pattern
Optimize on-farm management practices Adopt improved irrigation technology authorities released an ordinance on restriction of groundwater resources (TRBMB 2008), still one-third of sampled farmers would circumvent this regulation. There is strong evidence that the drastic increase in water price might lead to a further expansion of groundwater exploitation in the Tarim Basin. This effect has already been recognized by Schuck and Green (2003) for arid western United States and Liao et al. (2008) for different parts of China.

Out of the 128 sampled farm households, 32 decided to 'do nothing, and just pay higher water price'. It may either be that those farmers suppose their water-related farming practices cannot be further improved, or that the water price only plays a marginal role in their total farm budget. Furthermore, only a small share of farmers decided to 'shift crop pattern' $(8.6 \%)$ or 'improve on-farm management' $(5.4 \%)$ as a reaction to increased water price. It reveals that the farmers' knowledge of alternative crops with reduced water requirements, as well as their understanding of improved water use efficiency through improved farm management is limited. Finally, $31.3 \%$ of farmers decided to 'adopt improved irrigation technology' in case of increased water price. It indicates a high awareness among local farmers that improved irrigation technology can help to ease the tight water situation by improving water use efficiency.

Looking at farmers' reaction at the five survey sites, one can recognize only a slight variation over the locations (Fig. 2b). However, Xayar-North and Xayar-South feature a rather low rate of 'drill a well' compared to the other three sites. This may be a result of a more effective restriction of ground water extraction in the Xayar region compared to the other sites. Furthermore, farmers in Alar mentioned 'shift crop pattern' much more often compared to the other four sites, while they recognized 'adapt improved irrigation technology' much less an option towards increasing water price. All farmers in Alar belong to the XPCC. Therefore, a great share of crop production steps, including irrigation, is only in part managed by farmers, but mainly organized on tuan (regiment) or lian (company) level. Furthermore, the technological level is already relatively high within the XPCC compared to other regions in the Tarim Basin (Feike et al. 2014).

It seems that the sole increase of irrigation water price would have little prospect of success to increase water use efficiency at a substantial degree. The results show that only $45.3 \%$ of sampled farmers opt for decisions that would support a more wise use of water and could lead to an actual improvement of water use efficiency. The majority of farmers would decide for either 'do nothing', or even worse 'drill a well', which would lead to a further aggravation of the water scarcity issue.

\section{Factors influencing farmers' response}

The multinomial logistic regression model shown in Table 4 is statistically significant $\left(x^{2}=51.112 ; p<0.05\right)$. The dependent variable was regressed against the following factors: total land area, age, total farm income, water shortage, ethnicity, education level, location, existence of fruit production and existence of well. Four independent variables, namely ethnicity, major crop, number of crops and irrigation method, were excluded from the regression, due to high correlation with other variables and consecutive redundancy. 'Drill a well' was selected as reference category in the multinomial logistic regression model. From sustainability point of view it constitutes the most undesirable reaction by farmers towards increases in water price. Therefore, comparing it to the other possible 
Table 4 Results of the multinomial logistic regression analysis
* Significant at $p=0.1$

** Significant at $p=0.05$

*** Significant at $p=0.01$

${ }^{a}$ The reference category is: drill well

\begin{tabular}{|c|c|c|c|c|c|c|}
\hline \multirow[t]{2}{*}{ Farmers' response $^{\mathrm{a}}$} & \multirow[t]{2}{*}{$B$} & \multirow[t]{2}{*}{ SE } & \multirow[t]{2}{*}{ Sig. } & \multirow[t]{2}{*}{$\operatorname{Exp}(B)$} & \multicolumn{2}{|c|}{$\begin{array}{l}95 \% \text { Confidence interval for } \\
\operatorname{Exp}(B)\end{array}$} \\
\hline & & & & & Lower bound & Upper bound \\
\hline \multicolumn{7}{|l|}{ Do nothing } \\
\hline Age & 0.044 & 0.024 & $0.067^{*}$ & 1.045 & 0.997 & 1.095 \\
\hline Area of total land & 0.021 & 0.010 & $0.033 * *$ & 1.021 & 1.002 & 1.042 \\
\hline Total farm income & 0.000 & 0.000 & $0.043 * *$ & 1.000 & 1.000 & 1.000 \\
\hline Location-Aksu-Awat & 1.962 & 1.619 & 0.225 & 7.117 & 0.298 & 169.995 \\
\hline Location-Alar & 1.815 & 1.461 & 0.214 & 6.141 & 0.351 & 107.564 \\
\hline Location-Xayar-North & 1.412 & 1.120 & 0.207 & 4.105 & 0.457 & 36.890 \\
\hline Location-Xayar-South & 1.124 & 1.273 & 0.377 & 3.078 & 0.254 & 37.348 \\
\hline Education-low education & 1.721 & 1.067 & 0.107 & 5.592 & 0.691 & 45.259 \\
\hline Education-high education & 0.306 & 1.273 & 0.810 & 1.358 & 0.112 & 16.449 \\
\hline Water shortage-slight & 1.976 & 0.720 & $0.006 * * *$ & 7.213 & 1.760 & 29.567 \\
\hline Well-no & 0.227 & 0.632 & 0.719 & 1.255 & 0.364 & 4.330 \\
\hline Fruits-no & 2.081 & 1.101 & $0.059 *$ & 8.015 & 0.926 & 69.379 \\
\hline \multicolumn{7}{|l|}{ Improve crop production } \\
\hline Age & -0.002 & 0.029 & 0.940 & 0.998 & 0.943 & 1.056 \\
\hline Area of total land & 0.032 & 0.014 & $0.028 * *$ & 1.032 & 1.003 & 1.062 \\
\hline Total farm income & 0.000 & 0.000 & $0.036 * *$ & 1.000 & 1.000 & 1.000 \\
\hline Location-Aksu-Awat & 5.618 & 3.580 & 0.117 & 275.294 & 0.247 & $306,735.248$ \\
\hline Location-Alar & 6.768 & 3.522 & $0.055^{*}$ & 869.477 & 0.873 & $865,499.696$ \\
\hline Location-Xayar-North & 4.890 & 3.242 & 0.131 & 132.974 & 0.231 & $76,465.473$ \\
\hline Location-Xayar-South & 4.885 & 3.361 & 0.146 & 132.346 & 0.182 & $96,049.209$ \\
\hline Education-low education & 0.089 & 1.031 & 0.932 & 1.093 & 0.145 & 8.241 \\
\hline Education-high education & -0.813 & 1.306 & 0.533 & 0.443 & 0.034 & 5.736 \\
\hline Water shortage-slight & 1.620 & 0.859 & $0.059 *$ & 5.051 & 0.938 & 27.182 \\
\hline Well-no & -0.382 & 0.777 & 0.623 & 0.683 & 0.149 & 3.128 \\
\hline Fruits-no & 2.705 & 1.180 & $0.022 * *$ & 14.954 & 1.479 & 151.151 \\
\hline \multicolumn{7}{|c|}{ Adopt improved irrigation technology } \\
\hline Age & 0.035 & 0.023 & 0.125 & 1.035 & 0.990 & 1.082 \\
\hline Area of total land & 0.014 & 0.009 & $0.099 *$ & 1.015 & 0.997 & 1.032 \\
\hline Total farm income & 0.000 & 0.000 & 0.142 & 1.000 & 1.000 & 1.000 \\
\hline Location-Aksu-Awat & 2.221 & 1.527 & 0.146 & 9.220 & 0.462 & 183.966 \\
\hline Location-Alar & 0.217 & 1.395 & 0.876 & 1.243 & 0.081 & 19.131 \\
\hline Location-Xayar-North & 0.967 & 0.949 & 0.308 & 2.630 & 0.410 & 16.890 \\
\hline Location-Xayar-South & 1.087 & 1.060 & 0.305 & 2.965 & 0.372 & 23.652 \\
\hline Education-low education & 0.810 & 0.875 & 0.355 & 2.248 & 0.404 & 12.498 \\
\hline Education-high education & -0.617 & 1.088 & 0.571 & 0.540 & 0.064 & 4.556 \\
\hline Water shortage-slight & 1.895 & 0.701 & $0.007 * * *$ & 6.656 & 1.685 & 26.284 \\
\hline Well-no & 0.599 & 0.607 & 0.323 & 1.821 & 0.554 & 5.981 \\
\hline Fruits-no & 3.173 & 1.231 & $0.010 * * *$ & 23.869 & 2.140 & 266.261 \\
\hline
\end{tabular}

reactions helps to develop recommendations for a more sustainable water use.

When comparing the probability of farmers to 'dig a well' and 'do nothing, but just pay higher water price', five variables namely total land area, age, total farm income, slight water shortage and existence of fruit production had a statistically significant impact. The results show that farmers who had more land as well as higher income were more likely to 'do nothing' than 'drill a well'. This may be explained by the marginal share that water price constitutes in their total budget. At a cash income of more than 45,000 RMB per hectare observed for the 80th percentile of farm households a $100 \%$ increase in water price from 1,000 to 2,000 RMB per hectare may not affect their decision in this 
respect. Furthermore, did older farmers show a slight tendency towards 'do nothing', which may be caused by their reluctance to undertake big investments in the light of the approaching retirement (Potter and Lobley 1992), instead of accepting the relatively small annual burden of water price increase. In addition, farmers who suffered from slight water shortage were more likely to choose 'do nothing' than 'drill a well'. Even this might seem paradoxical at first sight, it may also be the result of high investment costs of well drilling, being disproportionately high compared to the monetary losses caused by slight water shortage. Finally, the probability of farmers having no fruit production is higher to 'do nothing' than 'drill well'. As drilling of a well is a similar venture like the establishment of an orchard, regarding long-term planning and investment, it can explain the correlation between those two factors.

The model furthermore estimated five variables to be significant when comparing the choice of 'improve crop production' and 'drill a well'. The results illustrate that farmers who had more land and high income were more likely to choose 'improve crop production' under conditions of increased water price. This result is supported by the argument that larger land tenure, accompanied by higher capital capacity, allows bearing more risk, e.g., by shifting to other crops, compared to small-scale farmers (Norris and Batie 1987). Besides, farmers who did not have fruit trees were more likely to choose other options if water pricing increase. The major reason behind this may be the fact that farmers who only grow annual crops can easily shift to other crops compared to those farmers who established a fruit plantation on their land, and would lose their investment by shifting to other crops. In addition, slight water shortage and location showed a certain influence on farmers' choice.

The comparison between the choices of 'adopt improved irrigation technology' and 'drill a well' indicates that three variables, namely total land area, slight water shortage, and no fruits, were statistically significant. First of all, farmers with larger total land area were more likely to adapt improved irrigation technology. However, the level of significance was much lower compared to the impact of land area in the other two cases presented above. Furthermore, farmers who suffered from slight water shortage were more likely to adopt improved irrigation technology under increased water price. The results show that the odd of choosing 'adopt improved irrigation technology' was more than six times higher for farmers who suffered from slightly water shortage, than the odd of farmers who did not suffer from water shortage and the odd of farmers who suffered from severe water shortage. At the same time no significant impact is estimated for farmers who suffered high water shortage. As the adoption of improved irrigation technology can increase water use efficiency to a certain extent ( $\mathrm{Li}$ et al. 2008), it seems a viable option to counteract slight water shortage, by allocating the limited water resources efficiently over the entire farms' cropping area. However, in case of severe water shortage and related times of complete absence of water, adoption of improved irrigation technology is obviously only a small part of the solution.

Finally, farmers who did not have fruit were more likely to adopt improved irrigation technology under increased water price. The odd of choosing 'adopt improved irrigation technology' for farmers who did not have fruit trees was almost 24 times that of farmers who had fruit trees. This vice versa indicates that farmers who had fruit trees were less likely to adopt improved irrigation technology. In recent years, several studies were conducted in arid northwestern China, testing the effect of the application of improved irrigation technology on major fruit trees' growth and yield. The results show that adopting improved irrigation technology can increase water use efficiency of fruit trees significantly (e.g., Cui et al. 2008; Du et al. 2008; Yang et al. 2013). However, fruit farmers in the Tarim Basin apparently are not convinced of the benefits related to adopting improved irrigation technology. The source of this problem may be the lack of effective transfer of the related research findings to the farmers, which is a common challenge in Chinese agricultural research (Feike et al. 2010).

\section{Conclusion and recommendations}

Farm household interviews were conducted to find out farmers' response towards a strong increase in water price along the Tarim River. The results show that increasing irrigation water price induces $<50 \%$ of the interviewed farmers to use water more wisely, by adopting improved irrigation technology, shift to crops which need less water, or improve farm management to generate higher returns with less water. On the contrary, more than $50 \%$ of farmers would either implement no changes in their farm management practices, or-even worse-would feel encouraged to drill a well and establish their own source of water. Thus, the increase in water price may actually foster the overexploitation of ground water resources in the Tarim Basin.

When determining which factors influence farmers' reaction towards the increase in water price employing multinomial logistic regression, the results show that farmers with larger land area tended to opt for other options than 'drill well'. In reverse farmers with smaller land area felt more encouraged to 'drill well' when water price increases. Furthermore, slight water shortage 
decreased the probability that farmers 'drill well' compared to the probability that they 'do nothing' or 'adopt improved irrigation technology'. Finally farmers involved in perennial fruit production are more likely to 'drill well' compared to the other three options. Conversely, farmers only producing annual crops are more motivated to 'do nothing', 'improve crop production' and 'adopt improved irrigation technology'.

The results indicate that solely increasing water price at a high rate is not a viable option to improve water resource use in the study region. To overcome the tight water situation and realize a wiser use of water, it is indispensable to develop and implement an integrated approach. First of all, it is essential to create awareness among all agricultural water users that their unwise use of water may cause water shortage for other farmers. There is strong indication that farmers who already suffered slight water shortage are more willing to opt for wiser water use decisions. Furthermore, agricultural extension service needs to be advanced to enable local farmers to increase their monetary benefits from the limited water resources. Up to now, the majority of farmers seem to lack knowledge and skills of how to improve their farms' water productivity. In addition, an effective control of ground water drilling needs to be enacted to avoid further environmental degradation. Special attention should be put on small-scale farmers, and especially fruit farmers, who up to now seem not convinced of the benefits of using advanced irrigation technology in orchards.

Acknowledgments This research was embedded in the SuMaRiO (Sustainable Management of River Oases along the Tarim River) project, funded by the German Federal Ministry of Education and Research through the "Sustainable Land Management" program. We furthermore acknowledge the support of Dr. Ling Yee Khor regarding the choice of regression model.

Open Access This article is distributed under the terms of the Creative Commons Attribution License which permits any use, distribution, and reproduction in any medium, provided the original author(s) and the source are credited.

\section{References}

Abu-Zeid M (2001) Water pricing in irrigated agriculture. Int J Water Resour Dev 17:527-538

Albiac J, Playan E, Martinez Y (2007) Instruments for water quantity and quality management in the agriculture in Aragon. Int J Water Resour Dev 23:147-164

Aishan T, Halik Ü, Kurban A, Cyffka B, Kuba M, Betz F (2013) Ecomorphological response of floodplain forests (Populus euphratica Oliv.) to manmade water diversion in the lower reaches of Tarim River, Xinjiang, Northwest China. Environ Earth Sci. doi:10.1007/s12665-013-3033-4

Bakopoulou S, Polyzos S, Kungolos A (2010) Investigation of farmers' willingness to pay for using recycled water for irrigation in Thessaly region, Greece. Desalinization 250:329-334
Berbel J, Gómez-Limón JA (2000) The impact of water-pricing policy in Spain: an analysis of three irrigated areas. Agric Water Manag 43(2):219-238

BTSYB (2012) Bingtuan statistical yearbook. National Bureau of Statistics, China Statistical Press, Beijing

Chen Y, Li W, Xu C, Ye Z, Chen Y (2013a) Desert riparian vegetation and groundwater in the lower reaches of the Tarim River Basin. Environ Earth Sci. doi:10.1007/s12665-013-3002-y

Chen Y, Xu C, Chen Y, Liu Y, Li W (2013b) Progress, challenges and prospects of eco-hydrological studies in the Tarim River basin of Xinjiang, China. Environ Manage 51:138-153

Christopoulou O, Minetos D (2009) Afforestation of rural land in Greece: a multinominal logistic regression analysis of driving forces. Int J Sustain Dev Plan 4(3):238-257

Cui N, Du T, Kang S, Li F, Zhang J, Wang M, Li Z (2008) Regulated deficit irrigation improved fruit quality andwater use efficiency of pear-jujube trees. Agric Water Manag 95(4):489-497

de la Paix MJ, Lanhai L, Jiwen G, de Dieu HJ, Theoneste N (2012) Analysis of snowmelt model for flood forecast for water in arid zone: case of Tarim River in Northwest China. Environ Earth Sci 66(5): 1423-1429

Demeke AB, Keil A, Zeller M (2011) Using panel data to estimate the effect of rainfall shocks on small holders food security and vulnerability in rural Ethiopia. Clim Change 108:185-206

Dinar A, Subramanian A (1998) Policy implications from water pricing experiences in various countries. Water Policy 1:239-250

Doppler W, Salman AZ, Al-Karabieh EK, Wolff H (2002) The impact of water price strategies on the allocation of irrigation water: the case of the Jordan Valley. Agric Water Manag 55:171-182

Du T, Kang S, Zhang J, Li F, Yan B (2008) Water use efficiency and fruit quality of table grape under alternatepartial root-zone drip irrigation. Agric Water Manag 95(6):659-668

Feike T, Chen Q, Graeff-Hönninger S, Pfenning J, Claupein W (2010) Farmer-developed vegetable intercropping systems in southern Hebei, China. Renew Agric Food Syst 25:272-280

Feike T, Mamitimin Y, Li L, Doluschitz R (2014) Development of agricultural land and water use and its driving forces along the Aksu and Tarim River, P.R. China. Environ Earth Sci. doi:10. 1007/s12665-014-3108-x

Frija A, Wossink A, Buysse J, Speelman S, Van Huylenbroeck G (2011) Pricing policies and impact on water demand in Tunisia: a DEA-based methodology for estimation of individual input demand functions. J Environ Manage 92:2109-2118

$\mathrm{Fu} \mathrm{A}, \mathrm{Li}$ W, Chen Y (2012) The threshold of soil moisture and salinity influencing the growth of Populus euphratica and Tamarix ramosissima in the extremely arid region. Environ Earth Sci 66(8):2519-2529

Gómez-Limón JA, Riesgo L (2004) Irrigation water pricing: differential impacts on irrigated farms. Agric Econ 31:47-66

Hazell PBR, Norton RD (1986) Mathematical programming for economic analysis in agriculture. Macmillan, New York

Henseler M, Wirsig A, Herrmann S, Krimly T, Dabbert S (2009) Modeling the impact of global change on regional agricultural land use through an activity-based non-linear programming approach. Agric Syst 100:31-42

Howitt RE (1995) Positive mathematical programming. Am J Agric Econ 77:329-342

Huang X, Chen Y, Ma J, Hao X (2011) Research of the sustainable development of Tarim River based on ecosystem service function. Procedia Environ Sci 10:239-246

Jiang L, Tong Y, Zhao Z, Li T, Liao J (2005) Water resources, land exploration and population dynamics in arid areas-the case of the Tarim River Basin in Xinjiang of China. Popul Environ 26:471-503

Li Y, Pang H, Zhang H, Chen F (2008) Effect of irrigation management on soil salinization in Manas River Valley, Xinjiang, China. Front Agric China 2(2):216-223 
Liao Y, Giordano M, de Fraiture C (2007) An empirical analysis of the impacts of irrigation pricing reforms in China. Water Policy 9:45-60

Liao Y, Gao Z, Bao Z, Huang Q, Feng G, Xu D, Cai J, Han H, Wu W (2008) China's water pricing reforms for irrigation: effectiveness and impact. Comprehensive assessment of water management in agriculture discussion paper 6. International Water Management Institute, Colombo, Sri Lanka. http://www.iwmi.cgiar.org/Assess ment/files_new/publications/Discussion\%20Paper/CADiscussion Paper6.pdf. Accessed 12 June 2013

Molle F (2008) Can water pricing policies regulate irrigation use? In: Paper presented at 13th world water congress, Montpellier, France, 1-4 September 2008. http://www.academia.edu/880390/ Can_water_pricing_policies_regulate_irrigation_use. Accessed 1 March 2013

Nikouei A, Zibaei M, Ward FA (2012) Incentives to adopt irrigation water saving measures for wetlands preservation: an integrated basin scale analysis. J Hydrol 464-465:216-232

Norris PE, Batie SS (1987) Virginia farmers' soil conservation decisions: an application of Tobit analysis. South J Agric Econ 19:79-90

Perry C (2001) Water at any price? Issues and options in charging for irrigation water. Irrig Drain 50(1):1-7

Potter C, Lobley M (1992) Ageing and succession of family farms: the impact on decision-making and land use. Sociol Rural $32(2 / 3): 317-334$

Reddy VR (2009) Water pricing as a demand management option: potentials, problems and prospects. In: Saleth RM (ed) Strategic analyses of the national river linking project (NRLP) of India, series 3: promoting irrigation demand management in India: potentials, problems and prospects. International Water Management Institute (IWMI), Colombo

Schoengold K, Sunding DL, Moreno G (2006) Price elasticity reconsidered: panel estimation of an agricultural water demand function. Water Resour Res 42

Schuck E, Green GP (2003) Conserving one water source at the expense of another: the role of surface water price in adoption of wells in a conjunctive use system. Int J Water Resour Dev 19:55-66

Shen Y, Haakon L (2010) Treating water as an economic good: policies and practices in irrigation agriculture in Xinjiang, China. Geogr J 176(2):124-137

Singh K (2007) Rational pricing of water as an instrument of improving water use efficiency in the agricultural sector: a case study in Gujarat, India. Int J Water Resour Dev 23:679-690

Song Y, Wang R, Peng Y (2002) Water resources and ecological conditions in the Tarim Basin. Sci China 45:11-17

Speelman S, Buysse J, Farolfi S, Frija A, D'Haese M, D'Haese L (2009) Estimating the impacts of water pricing on smallholder irrigators in North West Province, South Africa. Agric Water Manag 96:1560-1566

Tardieu H, Prefol B (2002) Full cost or 'sustainable cost' pricing in irrigated agriculture. Charging for water can be effective but is it sufficient? Irrig Drain 51:97-107

Thevs N (2011) Water scarcity and allocation in the Tarim Basin: decision structures and adaptations on the local level. J Curr Chin Aff 40(3):113-137
Tiwari DN, Dinar A (2001) Role and use of economic incentives in irrigated agriculture. Working Paper. World Bank, Washington DC. http://siteresources.worldbank.org/INTARD/8414381111130534002/20434289/RoleandUseofEconomicIncentivesPa per.pdf. Accessed 25 Jan 2013

TRBMB (Tarim River Basin Management Bureau) (2008) Tarim River Basin management bureau strengthens protection and management of the Tarim River Basin watercourses and groundwater management within the Basin, Xinjiang Tarim River Basin Management Bureau, Korla. http://www.tahe.gov. $\mathrm{cn} / \mathrm{e} / \mathrm{action} / \mathrm{ShowInfo}$.php?classid=65\&id=8828. Accessed 11 July 2013 (in Chinese)

Tsur Y (2005) Economic aspects of irrigation water pricing. Can Water Res J 30:31-46

Tsur Y, Dinar A (1997) The relative efficiency and implementation costs of alternative methods for pricing irrigation water. World Bank Econ Rev 11:243-262

Varela-Ortega C, Sumpsi JM, Garrido A, Blanco M, Iglesias E (1998) Water pricing policies, public decision making and farmers' response: implications for water policy. Agric Econ 19:193-202

Winpenny J (1994) Managing water as an economic resource (development policies studies). Routledge and Overseas Development Institute, London

Wu J (2012) Evaluation of the water resource reproducible ability on Tarim River Basin in south of Xinjiang, northwest China. Environ Earth Sci 66(7):1731-1737

XJSYB (2012) Xinjiang statistical yearbook. National Bureau of Statistics, China Statistical Press, Beijing

Xu F, Li Y, Ren SM (2003) Investigation and discussion of drip irrigation under mulch in Xinjiang Uygur Autonomous Region. Trans Chin Soc Agric Eng 19(1):25-27 (in Chinese)

$\mathrm{Xu} \mathrm{H}$, Ye M, Song Y (2005) The dynamic variation of water resources and its tendency in the Tarim River Basin. J Geog Sci 15:467-474

Xu J, Chen Y, Li W, Zhang L, Hong Y, Bi X, Yang Y (2012) Statistical analysis of groundwater chemistry of the Tarim River lower reaches, Northwest China. Environ Earth Sci 65(6): 1807-1820

Yang Q, Zhang F, Li F, Liu X (2013) Hydraulic conductivity and water-use efficiency of young pear tree underalternate drip irrigation. Agric Water Manag 119:80-88

Ye M, Xu H, Song Y (2006) The utilization of water resources and its variation tendency in Tarim River Basin. Chin Sci Bull 51(1):16-24

Zhao R, Chen Y, Shi P, Zhang L, Pan J, Zhao H (2013) Land use and land cover change and driving mechanism in the arid inland river basin: a case study of Tarim River, Xinjiang, China. Environ Earth Sci 68(2):591-604

Zhou H, Zhang X, Xu H, Ling H, Yu P (2012) Influences of climate change and human activities on Tarim River runoffs in China over the past half century. Environ Earth Sci 67(1):231-241 